\title{
Income Smoothing Using Reserve Accounts By Japanese Companies
}

Wikil Kwak, (E-mail: wkwak@mail.unomaha.edu), University of Nebraska at Omaha Ho-Young Lee, (E-mail: hylee@base.yonsei.ac.kr), Yonsei University, South Korea

\begin{abstract}
This paper examines income-smoothing by Japanese firms using several reserve accounts. Previous studies investigated the incentives for Japanese managers to smooth income using sales of assets, discretionary accounting accruals or depreciation charges under different operating environments. Discretion in reserve accounts as a means of income-smoothing, however, has not yet been investigated. Understanding Japanese managers' earnings management via reserve accounts is particularly interesting because of the unique legal environment for reserve accounts. We find that income-smoothing via reserve accounts is associated with size, tax, capital intensity, operating deviations, leverage, earnings variability, and securities offerings. When we partition the sample to take into account the substantial structural changes in Japan in 1990, the effects of several variables appear to be different over the two periods.
\end{abstract}

\section{INTRODUCTION}

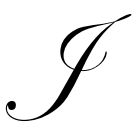

apanese laws and Generally Accepted Accounting Principles (GAAP) mandate various reserve accounts. One unexpected result of this requirement is to increase management opportunities for income-smoothing.

Managers do this in order to maintain target income levels, to avoid the violation of debt covenants or to avoid political costs, etc. Prior studies have examined several means of earnings management in the U.S. and Japan, such as asset sales (Bartov 1993; Poitras et al. 2002; Herrmann et al. 2003), loan loss provisions (Kanagaretnam et al. 2003; Kanagaretnam et al. 2004), discretionary accounting accruals (Jones 1991; Wu 1997; Teoh et al. 1998), or depreciation charges in different operating environments (Herrmann et al. 1996). Reserve accounts represent another important means for income-smoothing, but one that has not well been understood. Japanese laws and GAAP allow managers to create and use various reserve accounts, and also give considerable discretion in the treatment of these accounts.

The purpose of this study is to examine whether Japanese managers, when faced with certain incentives, use reserve accounts to smooth income. Various reserve accounts are unique to Japanese financial statements. Under Japanese law, firms have been required, from April $20^{\text {th }}, 1982$, to set up reserves for their guaranteed obligations (Takahashi et al. 1984). These reserve accounts, however, can be used as a means for smoothing earnings because rules on reserve accounts are loose and require managerial judgment. Corporate accounting principles and tax laws in Japan do not provide detailed guidelines for computing reserve accounts. Also, within the rules, there is flexibility in determining reserves for a given year. Japanese managers, therefore, may be faced with more opportunities to use reserve accounts to smooth income than their counterparts in the U.S.

These reserve accounts are large enough to materially affect the financial statements. Sony Corporation's reserve accounts in 1990, for example, totaled 34,113 million Yen, equivalent to 5 percent of retained earnings. The Japanese Commercial Code also requires firms to reserve an amount equal to at least 10 percent of cash dividends until the accumulated reserve becomes 25 percent of the capital stock. Despite the clear importance of reserve accounts in financial statements, no prior study has examined whether managers use them to smooth income. This paper, in examining Japanese firms that have more managerial discretion in reserve accounts, looks at important factors known to be related to income-smoothing, and attempts to determine whether Japanese managers use reserve accounts to 
smooth income. The paper will, therefore, provide useful information to investors, regulators, and other users of financial statement in their future decision-making.

The next section presents background on earnings management, and the economic and legal environment in Japan during the sample period. The third section describes research methodology and data collection procedures; the fourth section reports the results of our empirical analyses and discusses additional analysis. The paper concludes with a summary of our findings and suggestions for future research.

\section{BACKGROUND}

The potential for Japanese managers to smooth income using accounting discretion in reserve accounts is greater than in other major industrialized countries, mainly because so much discretion is permitted in reserve accounting procedures. In particular, reserve accounts can be used as a primary means of income-smoothing because of their complexity and the management discretion available. Firms use various types of reserve accounts, including reserves for loan losses, corporate taxes, business taxes, bonuses, special reserves, legal reserves, capital reserves, and earned reserve accounts, amongst others.

Several U.S. studies have examined factors related to earnings management. Moses (1987), for example, uses specific firm characteristics that may provide incentives for managers to make accounting choices that smooth earnings. His results show that income-smoothing is associated with firm size, the existence of bonus compensation plans, and variations in earnings. Jones (1991) tests whether an import relief assessment by the International Trade Commission (ITC) is associated with discretionary accruals; she reports that managers decrease earnings through discretionary accruals during import relief investigations. Dechow and Sloan (1991) investigate whether firms use discretionary cash flows to improve short-term earnings performance when CEOs are in their final years in office; their results suggest that these CEOs spend less on research and development.

Maydew (1997) tests empirically whether corporate income tax induces earnings management by firms with net operating losses; he finds that firms manage their earnings by disaggregating shifted income into recurring and non-recurring revenue and expense components. Dechow et al. (1995) find that a firm's financial performance affects managers' incentives for earnings management. Kasznik (1999) also finds that firms with earnings falling below management forecasts have more positive discretionary accruals in that year than in other years. These studies provide empirical evidence of earnings management in the U.S. context.

Several studies have examined factors that affect Japanese managers' incentives for earnings management. Herrmann and Inoue (1996) empirically tested income-smoothing using changes in depreciation methods. They find that, under certain operating conditions, firm size, income taxes, capital intensity, deviations from expected operating activities, and earnings variability are all related to income-smoothing via changes in depreciation method. Herrmann et al. (2003) use income from the sale of fixed assets and marketable securities to test Japanese managers' earnings management. They find that income from sales of assets and management forecast error have a negative relationship, after controlling for debt-to-equity ratio, firm size, growth, and last year's income from asset sales. Darrough et al. (1998) examine choices in accounting accruals, and find that the capital structure of Japanese firms is associated with earnings management only after the 1990 market crash. They also find that, regardless of their unique business environment (such as long-term orientation and tax-aligned accounting practices), Japanese managers choose accounting accruals that increase income, in order to increase bonuses and augment outside funding.

While reserve accounts are subject to considerable management discretion, their use as a means of income-smoothing has not been well understood, or, indeed, examined at all. In particular, the unique Japanese legal and accounting environments for reserve accounts give stakeholders powerful motivation to examine whether these reserve accounts can be used for income-smoothing. 


\section{RESEARCH METHODOLOGY}

\section{Income-Smoothing Measures}

Assuming a random walk expectation of earnings $(E)$ and earnings before provisions on reserve accounts $(E B R)$, a measure of income-smoothing $(I S)$ is calculated by comparing the absolute value of the one year difference in earnings before provisions on reserve accounts $(C E B R)$ with the absolute value of the one year difference in earnings $(C E)$. Firms with negative $C E B R$ are likely to have a greater incentive to smooth income using reserve accounts, in order to lower the difference between the two EBRs. Similarly to discretionary accruals models (see, for example, Dechow et al. 1995), this measure is scaled by the beginning-of-year total assets (ASSETS) to control for the effect of firm size, as presented in model (1).

$I S_{i t}=\frac{\left|E B R_{i t}-E B R_{i t-1}\right|-\left|E_{i t}-E_{i t-1}\right|}{A S S E T S_{i t-1}}$

where

$I S=$ a proxy of income-smoothing;

$E B R=$ earnings before provisions on reserve accounts;

$E=$ net income; and

ASSETS = beginning-of-year total assets.

A similar model is also used by Moses (1987) and Herrmann and Inoue (1996) in measuring income-smoothing. Positive values of $I S$ represent income-smoothing, as the absolute values for $C E B R$ are used to lower the absolute values of $C E$.

\section{Factors Related To Income-Smoothing}

We here discuss variables identified in prior studies as affecting managers' incentives for income-smoothing. We examine whether income-smoothing using reserve accounts is also associated with these factors.

Firm Size

Large firms have high public profiles, and so have greater incentive to maintain their reputations (Watts and Zimmerman 1986). Lang and Lundholm (1993) argue that large firms have greater incentives to disclose financial information accurately to avoid litigation. Fluctuations of income in large firms draw more attention from investors and/or creditors, increase litigation risk and may attract the attention of regulators (Benston and Krasney 1978). Consistent with this, Lee and Mande (2003) find a negative association between absolute discretionary accruals and size. Thus, larger firms may have less incentive to smooth earnings. Therefore, a negative association between firm size and income-smoothing is expected. Firm size (LNSIZE) is measured by the natural log of total assets.

Taxes

Tax laws are influenced by political, social and economic objectives (Ali and Hwang 2000). Tax reporting should provide managers with incentives to reduce taxes by reporting systematically low profits (Choi and Mueller 1992); this is particularly true under a progressive tax system. It is therefore expected that firms with greater current tax liabilities are more likely to smooth income under Japan's progressive tax system. In order to examine the tax incentives on income-smoothing, current year income tax expenses are deflated by sales $(T A X)$.

\section{Capital Intensity}

The proportion of fixed assets to total assets represents capital intensity. Firms with large investments in facilities and equipment are less likely to smooth income, because these accounts should have less accounting 
flexibility under historical cost accounting principles. Herrmann and Inoue (1996) find, however, that firms with large fixed assets are more likely to smooth earnings using changes in depreciation method. Therefore, to examine the effect of capital intensity on income-smoothing, net tangible fixed assets deflated by total assets (INTEN) are included. The sign of this variable is an empirical question.

\section{Operating Activity Deviation}

Managers may have greater motivation to smooth income if actual operating results deviate from expected operating results. Japanese firms tend to focus on sales growth as their main goal (Radebaugh and Gray 1997), and so sales are used to measure deviation in operating activities. The deviation is measured as the absolute value of the change in sales deflated by prior year sales $(D E V)$, and is expected to have a positive association with income-smoothing.

\section{Earnings Variability}

Daley et al. (1988) find that variability in earnings increases firm risk and therefore increases cost of capital. If this is the case, managers who have experienced high variability in earnings have greater incentive to smooth income, in order to lower the cost of capital. A positive association is therefore expected between income-smoothing and past earnings variability. Earnings variability $(E V A R)$ is measured as the absolute value of the change in earnings divided by sales averaged over the last three years, including the current year.

\section{Debt-to-Equity Ratio}

U.S. studies find that leverage is positively associated with management incentive for earnings management (Bowen et al. 1981; Dhaliwal et al. 1982; Watts and Zimmerman 1986). Public ownership is, however, less prevalent in Japan than in the U.S. (Black and White 2003). Also, Japanese firms depend more on bank debt and banks are, at the same time, some of the largest shareholders. Banks therefore closely monitor firms' accounting practices, and firms find it more difficult to smooth income. It is an empirical question as to whether and how the debt-to-equity ratio $(D T E Q U)$ is associated with income-smoothing in Japan.

\section{Return on Assets}

Kim et al. (2003) and Heflin et al. (2002) find that profitable firms are less likely to use income-increasing discretionary accruals. On the other hand, firms with large profits may want to smooth earnings so that they can show continued future growth (Libby and Kinney 2000). The direction of the effect from a firm's profitability, therefore, is an empirical question. Return on assets $(R O A)$ is used to measure profitability, calculated as the ratio of net income to total assets averaged over the last three years, including the current year.

\section{Changes in Depreciation Expenses}

Depreciation expenses can be used as a means for smoothing earnings (Moses 1987). Firms smoothing earnings using depreciation expenses are also likely to use reserve accounts for additional income-smoothing. In order to examine whether there is an association between depreciation expenses and income-smoothing, we include changes in depreciation expenses over one year deflated by the previous year's sales (CGDEP).

Stock Issuance

Managers have more incentive to smooth income prior to securities offerings (Rangan 1998; Teoh et al. 1998); stock issuance, therefore, is expected to be positively associated with income-smoothing. Stock issuance is measured as stock issuance in the following year deflated by current year total assets (ISSUE).

In order to examine the association between the variables discussed above and income-smoothing, the following regression model is used: 


$$
\begin{aligned}
& I S_{i t}=\alpha_{0 i t}+\beta_{1} L_{N S I Z E_{i t}}+\beta_{2} T A X_{i t}+\beta_{3} I_{N T E N}+\beta_{4} D E V i t+\beta_{5} E V A R_{i t}+\beta_{6} D T E Q U_{i t} \\
& +\beta_{7} \text { ROA }_{i t}+\beta_{8} \text { CGDEP }_{i t}+\beta_{9} \operatorname{ISSUE}_{i t}+\sum_{k} \gamma_{k} \text { INDUSTRY }_{k i t}+\sum_{l} \eta_{l} Y E_{\text {it }}+\varepsilon_{i t}
\end{aligned}
$$

\section{Data Collection And Descriptive Statistics}

Following Takahashi (1984), our sample period consists of firm-years from 1982 through 1999 in the PACAP and OSIRIS databases for Japan. A total of 27,061 non-financial and non-regulated firm-years are available between 1982 and 1999. Financial and regulated firms are excluded due to their non-homogeneous business environment and firm characteristics. We then exclude firms which do not have a March 31st fiscal year-end, to control for the information environment (leaving 19,534 firm-years). Excluding firm-years without the necessary financial data for the regression model leaves 19,029 firm-years. Table 1 presents the number of observations of reserve accounts by industry and year. The sample firms represent a wide range of industries, with about 25 percent coming from Chemicals and Electric Machinery.

\section{RESULTS AND ADDITIONAL TESTS}

Descriptive statistics for the variables used in our regression are presented in Table 2. The table shows that the median value of tax expenses accounts for about 1.5 percent of sales, while the mean value of fixed assets accounts for about 22 percent of total assets. To eliminate potential effects from outliers, the top and bottom 1 percent of continuous variables are winsorized. Using unwinsorized values does not change our conclusions on any of the variables, but lowers statistical significance for some of the variables. The Pearson correlation matrix (not reported) shows that there are generally no large correlations between the independent variables used in our regression analyses. The largest correlation is between ROA and DTEQU $(\rho=-35.86)$. Eliminating one of these variables does not affect our conclusions (in fact, it improves the statistical significance of other variables).

Table 3 provides results of our main regression using the full sample. The adjusted $\mathrm{R}^{2}$ of the regression is 0.2347. Firm size (LNSIZE) is significant and negatively associated with income-smoothing at the one percent level. Consistent with findings in previous U.S. studies, large firms in Japan have less incentive to smooth earnings. Capital intensity (INTEN) is also negatively associated with income-smoothing, which is consistent with our conjecture that capital-intense firms are less likely to smooth income, possibly because of reduced flexibility in the valuation of fixed assets under historical cost accounting principles. The debt-to-equity ratio $(D T E Q U)$ is negative and statistically significant at the one percent level, suggesting that debt-holders closely monitor accounting practices, thus preventing managers from income-smoothing behavior.

Income tax expense $(T A X)$ is positive and significant at the one percent level, consistent with our conjecture that managers with large tax liabilities are more likely to smooth earnings to minimize tax expenses under the Japanese progressive tax system. Deviations in operating activity $(D E V)$ and changes in depreciation expenses $(C G D E P)$ are positive and significant at the one percent level, suggesting that managers are more likely to smooth earnings when actual operating results deviate from expected results, and when depreciation expenses increase. Also, earnings variability $(E V A R)$ is positive and significant at the one percent level, suggesting that managers experiencing high variability in earnings are more likely to smooth earnings, possibly to reduce the cost of capital. Moses (1987) also argues that more fluctuations in earnings may result in higher borrowing rates or lower stock returns and, therefore, increase management incentive to smooth earnings. Finally, ISSUE is positive and significant at the one percent level, suggesting that managers who plan to issue equity stock are more likely to smooth earnings, in order to maximize the success of equity offerings. Neither the Variance Inflation Factor (VIF) nor the Condition Index (CI) indicate serious multi-collinearity problems (highest $\mathrm{VIF}=2.1$, highest $\mathrm{CI}=28.3$ ).

Table 4 presents smoothing behavior according to operating conditions. Profitable firms whose $C E B R$ is either positive or negative are presented according to the sign of income-smoothing. Overall, the number of income-smoothing firms (i.e., $I S>0, \mathrm{~N}=13,105$ ) is more than three times the number of non-income-smoothing firms (i.e., $I S \leq 0, \mathrm{~N}=3,605$ ). Firms experiencing losses are also presented in separate columns according to the sign of $I S$. 
The number of income-smoothing loss-making firms $(\mathrm{N}=1,342)$ is around 1.4 times that of the respective non-income-smoothing firms ( $\mathrm{N}=977$ ). The Chi-Square tests are performed to check the equal frequency of operating conditions for the profit and loss groups, respectively. For the profit group, 76.6 percent of positive $C E B R$ firms are classified in the income-smoothing group, while around 80.3 percent of negative $C E B R$ firms are classified in the income-smoothing group. For the profit group, the significant Chi-Square value is 33.87 (significant at the one percent level), indicating that income-smoothing via reserve accounts is different according to operating conditions. This finding is consistent with our expectation that negative $C E B R$ firms are more likely to smooth income via reserve accounts than positive $C E B R$ firms. Of the 564 firm-years with positive $C E B R$ and losses, 52.0 percent of them are classified in the income-smoothing group. On the other hand, 59.8 percent of firm-years with negative $C E B R$ and losses belong to the income-smoothing group. The Chi-square value is 10.71 (significant at the one percent level), indicating that firms with negative $C E B R$ and losses are more likely to smooth income via reserve accounts than firms with positive $C E B R$ and losses.

Table 5 presents four regression results under four different operating conditions. Consistent with our expectations, the overall significance of the model in the profit group is larger for the group with negative $C E B R$ than with a positive $C E B R$ (Adj- $\mathrm{R}^{2}=0.3552$ for negative $C E B R$ group vs. $A d j-\mathrm{R}^{2}=0.1500$ for positive $C E B R$ group). LNSIZE, TAX, INTEN, and DEV have larger coefficients and are statistically more significant than in model (B), Table 5. Models (A) and (B) in Table 5 show that deviations in operating activities (DEV) are important only for negative $C E B R$ firms, but profitability $(R O A)$ is an important motivation in income-smoothing only for positive $C E B R$ firms.

Similarly, for the loss-making group (models $\mathrm{C}$ and $\mathrm{D}$ ), the overall significance of the models is larger for the negative $C E B R$ group than that with positive $C E B R$ (Adj- $\mathrm{R}^{2}=0.4057$ for negative $C E B R$ group vs. Adj- $\mathrm{R}^{2}=0.2014$ for positive CEBR group). Also, ISSUE is of particular interest in both profit and loss groups: the results of models (B) and (D) suggest that firms close to a securities offering are very likely to smooth income via reserve accounts, and much more so for firms experiencing negative CEBR than firms experiencing positive CEBR. These results on ISSUE suggest that managers have strong capital markets-induced incentives for income-smoothing via reserve accounts, particularly when they have greater flexibility in reserve account treatment.

\section{Additional Analysis}

Japan experienced a market crash in 1990, and equity values dropped by more than half after the bursting of the bubble. It is therefore likely that there are differences in economic structure before and after 1990 (Darrough et al. 1998). Sample firm-years are divided into two groups: the pre-1990 sample includes firm-years from 1982 to 1989 , the post-1990 sample includes firm-years from 1992 through 1999. 1990 and 1991 are eliminated because they are transition years in the structural change. Table 6 reports the results of this comparison.

The overall significance of the models is greater for the pre-1990 period than the post-1990 period (Adj- $\mathrm{R}^{2}=$ 0.3085 for the pre-1990 group vs. Adj- $\mathrm{R}^{2}=0.1452$ for the post-1990 group). This may suggest that managers have experienced more difficulty in using reserve accounts for income-smoothing since 1990, possibly due to tighter regulatory and investor control over managers' accounting practices. All variable signs are consistent across the two periods, and are also consistent with those reported in the full sample regression. While LNSIZE, INTEN, DEV, EVAR, CGDEP and ISSUE are significant in both periods, several variables are significant only in one period. Table 6, model (A), shows that the debt-to-equity ratio (DTEQU) and profitability (ROA) are significant only pre-1990. Highly-levered firms are less likely to smooth income, suggesting that debt-holders monitor managers closely in Japan, discouraging income-smoothing. $R O A$ is positive and significant at the one percent level in model (A), suggesting that firms with profits may want to smooth their earnings in order to demonstrate continuous earnings growth. Table 6, model B, shows that tax expenses $(T A X)$ are significant only post-1990, suggesting that, since 1990, tax was a primary incentive for income-smoothing via reserve accounts.

The absolute values of the coefficients for $L N S I Z E, D T E Q U, R O A, C G D E P$, and ISSUE are greater and more significant during the pre-1990 period, while the absolute values of the coefficients for INTEN, DEV, and EVAR are greater and more significant for the post-1990 period. We examine the statistical differences in coefficients between the two periods using pooled regression with year interactions. The significances of incremental effects of each 
variable are reported in the last column of Table 6. All variables except INTEN and DEV are significantly different between the two periods. Overall, the results suggest that income-smoothing behavior has changed between the two periods, possibly because of the structural changes in Japanese economy and their business environment.

\section{SUMMARY AND CONCLUSIONS}

Ali and Hwang (2000) suggest that bank-oriented financial systems, the heavy involvement of private sector bodies in setting standards, and employing loose accounting standards in Japan may lower the value relevance of accounting information. The availability of more opportunities for income-smoothing would be one of the reasons for the low content of accounting information, relative to other developed countries. In particular, unlike other developed countries, Japanese firms use complex and numerous reserve accounts.

This study provides evidence that Japanese managers smooth income using reserve accounts. In particular, we find that income-smoothing is significantly associated with firm size, tax expenses, capital intensity, deviations from operating expectations, earnings variability, leverage, depreciation expenses and equity offerings. This study also finds that income-smoothing differs significantly according to operating conditions. Firms with a negative $C E B R$ have greater incentive for income-smoothing than those with positive $C E B R$, regardless of the current year's profit or loss. For profitable firms with negative $C E B R$, all variables used in the regression except $R O A$ are significantly associated with income-smoothing. For loss-making firms with negative CEBR, only LNSIZE, EVAR, ROA, and ISSUE are significant, suggesting that loss-making firms may have limited flexibility in smoothing income using reserve accounts, or may have fewer factors affecting incentives for income-smoothing.

Several limitations are acknowledged. Firstly, it is possible that firms use reserve accounts for strategic reasons, rather than as a means of income-smoothing. We were not able to control for firms' strategic reasons for reserve accounts, due to the lack of firm-specific long-term business information. Secondly, reserve provisions may be caused by changes in macro-economic factors other than the stock market crash of 1990. We therefore suggest that the effects of other macro-economic factors on income-smoothing should be investigated in detail in future research. Regardless of these limitations, our study contributes to the literature by providing the first evidence of income-smoothing using reserve accounts. The results of this study would be useful to multi-national investors considering investment into foreign countries, suggesting to enhancing their understanding of the unique accounting environment when interpreting financial statements.

\section{REFERENCES}

1. Ali, A., and L. S. Hwang. 2000. Country-specific factors related to financial reporting and the value relevance of accounting data. Journal of Accounting Research 38 (1): 1-21.

2. Bartov, E. 1993. The timing of asset sales and earnings manipulation. The Accounting Review 68 (October): 840-855.

3. Benston, G., and M. Krasney. 1978. The economic consequences of financial accounting statements. Financial Accounting Standards Board Research Report (March 1978): 159-252.

4. Black, E., and J. White. 2003. An international comparison of income statement and balance sheet information: Germany, Japan and the U.S. European Accounting Review 12 (1): 29-46.

5. Bowen, R., E. Noreen, and J. Lacey. 1981. Determinants of the corporate decision to capitalize interest. Journal of Accounting and Economics 3 (2): 151-179.

6. Choi, F., and G. Mueller, International Accounting, Englewood Cliffs, N. J.: Prentice-Hall, 1992.

7. Daley, L., D. Senkow, and R. Vigeland. 1988. Analysts' forecasts, earnings variability, and option pricing: empirical evidence. The Accounting Review 63 (4): 563-585.

8. Darrough, M., H. Pourjalali, and S. Saudagran. 1998. Earnings management in Japanese companies. The International Journal of Accounting 33 (3): 313-334.

9. Dechow, P., and R. Sloan. 1991. Executive incentives and the horizon problem: an empirical investigation. Journal of Accounting and Economics 14: 51-89.

10. Dechow, P., R. Sloan, and A. Sweeney. 1995. Detecting Earnings Management. The Accounting Review 70 (2): 193-225. 
11. Dhaliwal, D., G. Salamon, and E. Smith. 1982. The effect of owner versus management control on the choice of accounting methods. Journal of Accounting and Economics (4): 41-53.

12. Heflin, F., S. Kwon, and J. Wild. 2002. Accounting choices: variation in managerial opportunism. Journal of Business Finance \& Accounting 29 (7) \& (8): 1047-1078.

13. Herrmann D., and T. Inoue. 1996. Income-smoothing and incentives by operating condition: an empirical test using depreciation changes in Japan. Journal of International Accounting, Auditing \& Taxation 5 (2): 161-177.

14. Herrmann D., T. Inoue, and W. Thomas. 2003. The sales of assets to manage earnings in Japan. Journal of Accounting Research 41 (1): 89-108.

15. Jones, J. 1991. Earnings management during import relief investigations. Journal of Accounting Research 29: $193-228$.

16. Kanagaretnam, K., G. Lobo, and R. Matieu. 2003. Managerial incentives for income-smoothing through bank loan loss provisions. Review of Quantitative Finance and Accounting 20: 63-80.

17. Kanagaretnam, K., G. Lobo, and D. Yang. 2004. Joint tests of signaling and income-smoothing through bank loan loss provisions. Contemporary Accounting Research 21 (4): 843-884.

18. Kasznik R. 1999. On the association between voluntary disclosure and earnings management. Journal of Accounting Research 37 (1): 57-81.

19. Kim, J., R. Chung, and M. Firth. 2003. Auditor conservatism, asymmetric monitoring, and earnings management. Contemporary Accounting Research 20 (2): 323-359.

20. Lang, M., and R. Lundholm. 1993. Cross-sectional determinants of analyst ratings of corporate disclosures. Journal of Accounting Research 31 (Autumn): 246-271.

21. Lee, H., and V. Mande. 2003. The effect of the Private Securities Litigation Reform Act of 1995 on accounting discretion of client managers of Big 6 and Non-Big 6 auditors. Auditing: A Journal of Practice \& Theory 22 (1): 93-108.

22. Libby, R., and W. Kinney. 2000. Does mandated audit communication reduce opportunistic corrections to manage earnings to forecasts? The Accounting Review 75 (4): 383-404.

23. Maydew E. 1997. Tax-induced earnings management by firms with net operating losses. Journal of Accounting Research 35 (1): 83-96.

24. Moses, O. 1987. Income-smoothing and incentives: empirical tests using accounting changes. The Accounting Review LXII (2): 358-377.

25. Poitras, G., T. Wilkins, and Y. Kwan. 2002. The timing of asset sales: evidence of earnings management? Journal of Business Finance \& Accounting 29 (Sept/Oct.): 903-934.

26. Radebaugh, L., and S. Gary. 1997. International Accounting and Multinational Enterprises, $4^{\text {th }}$ Edition, New York: John Wiley.

27. Rangan, S. 1998. Earnings management and the performance of seasoned equity offerings. Journal of Financial Economics 50: 101-122.

28. Takahashi, K., Y. Kurokawa, and K. Watase. 1984. Corporate bankruptcy prediction in Japan. Journal of Banking and Finance 8: 229-247.

29. Teoh, S., I. Welch, and T. Wong. 1998. Earnings management and the long-run market performance of initial public offerings. The Journal of Finance LIII (December): 1935-1974.

30. Watts, R. and J. Zimmerman. 1986. Positive Accounting Theory, New Jersey: Prentice Hall, Englewood Cliffs, NJ.

31. Wu, W. 1997. Management buyouts and earnings management. Journal of Accounting, Auditing \& Finance 12 (Fall): 373-389. 
Table 1

Sample Distribution by Industry and Year

\begin{tabular}{|c|c|c|}
\hline Industry & $\begin{array}{c}\text { Number of } \\
\text { Firms }\end{array}$ & $\begin{array}{c}\text { Percent of } \\
\text { Sample }\end{array}$ \\
\hline Fishery & 85 & 0.45 \\
\hline Mining & 108 & 0.57 \\
\hline Construction & 1,904 & 10.01 \\
\hline Foods & 966 & 5.08 \\
\hline Textiles & 709 & 3.73 \\
\hline Pulp and Paper & 371 & 1.95 \\
\hline Chemicals & 2,235 & 11.75 \\
\hline Petroleum & 152 & 0.80 \\
\hline Rubber & 208 & 1.09 \\
\hline Glass and Ceramics & 490 & 2.58 \\
\hline Iron and Steel & 633 & 3.33 \\
\hline Nonferrous Metals & 555 & 2.92 \\
\hline Metal Products & 528 & 2.77 \\
\hline Machinery & 1,910 & 10.04 \\
\hline Electric Machinery & 2,550 & 13.40 \\
\hline Transportation Equipmer & 1,682 & 8.84 \\
\hline Precision Equipment & 452 & 2.38 \\
\hline Other Manufacturing & 602 & 3.16 \\
\hline Wholesale & 1,387 & 7.29 \\
\hline Retail & 516 & 2.71 \\
\hline Real Estate & 323 & 1.70 \\
\hline Service & 663 & 3.48 \\
\hline Totals & 19,029 & 100.00 \\
\hline
\end{tabular}

\begin{tabular}{|c|c|c|}
\hline Year & $\begin{array}{c}\text { Number of } \\
\text { Firms } \\
\end{array}$ & $\begin{array}{c}\text { Percent of } \\
\text { Sample }\end{array}$ \\
\hline 1982 & 662 & 3.48 \\
\hline 1983 & 676 & 3.55 \\
\hline 1984 & 698 & 3.67 \\
\hline 1985 & 720 & 3.78 \\
\hline 1986 & 782 & 4.11 \\
\hline 1987 & 915 & 4.81 \\
\hline 1988 & 1,041 & 5.47 \\
\hline 1989 & 1,101 & 5.79 \\
\hline 1990 & 1,125 & 5.91 \\
\hline 1991 & 1,154 & 6.06 \\
\hline 1992 & 1,200 & 6.31 \\
\hline 1993 & 1,232 & 6.47 \\
\hline 1994 & 1,267 & 6.66 \\
\hline 1995 & 1,276 & 6.71 \\
\hline 1996 & 1,298 & 6.82 \\
\hline 1997 & 1,304 & 6.85 \\
\hline 1998 & 1,297 & 6.82 \\
\hline 1999 & 1,281 & 6.73 \\
\hline Totals & 19,029 & 100.00 \\
\hline
\end{tabular}

Table 2

Descriptive Statistics $\mathrm{N}=19,029$

\begin{tabular}{|c|c|c|c|c|c|c|c|}
\hline Variables & Mean & St. Dev. & Min & Q1 & Median & Q3 & Max \\
\hline$I S$ & 0.0283 & 0.0597 & -0.0333 & 0.0002 & 0.0085 & 0.0288 & 0.3779 \\
\hline$L N S I Z E$ & 11.1370 & 1.3184 & 8.1662 & 10.2279 & 10.9822 & 11.9644 & 14.8458 \\
\hline$T A X$ & 0.0212 & 0.0240 & -0.0080 & 0.0042 & 0.0148 & 0.0294 & 0.1315 \\
\hline INTEN & 0.2416 & 0.1341 & 0.0134 & 0.1459 & 0.2260 & 0.3232 & 0.7508 \\
\hline$D E V$ & 0.0911 & 0.0863 & 0.0013 & 0.0308 & 0.0667 & 0.1228 & 0.4807 \\
\hline EVAR & 0.0505 & 0.0858 & 0.0008 & 0.0105 & 0.0224 & 0.0500 & 0.5845 \\
\hline$D T E Q U$ & 3.1788 & 4.4400 & 0.1342 & 0.9212 & 1.7499 & 3.4326 & 30.2523 \\
\hline$R O A$ & 0.0169 & 0.0240 & -0.0728 & 0.0062 & 0.0160 & 0.0296 & 0.0894 \\
\hline$C G D E P$ & -0.0008 & 0.0106 & -0.0516 & -0.0015 & 0.0001 & 0.0025 & 0.0301 \\
\hline ISSUE & 0.0392 & 0.1381 & 0.0000 & 0.0000 & 0.0000 & 0.0028 & 0.9472 \\
\hline
\end{tabular}

Variable definitions:

$I S=$ income-smoothing as defined in model (1);

$L N S I Z E=\log$ of total assets (in million of Yen) as of fiscal year-end;

$T A X=$ income tax divided by sales;

$I N T E N=$ net fixed assets divided by total assets;

$D E V=$ deviation in operating activities measured as $\frac{\left|S A L E S_{t}-S A L E S_{t-1}\right|}{S A L E S_{t-1}}$;

$E V A R=$ earnings variability measured as $\frac{1}{3} \sum_{t=-2}^{0}\left|\frac{E_{t}-E_{t-1}}{S A L E S_{t-1}}\right|$;

$D T E Q U=$ total debt-to-equity ratio;

$R O A=$ mean value of return on assets over the last 3 years including the current year;

$C G D E P=$ changes in depreciation expense deflated by prior year sales; and

$I S S U E=$ amount of stock issuance in the following year divided by current year total assets. 
Table 3

Regression Results - Full Sample

$$
\begin{aligned}
& I S_{i t}=\alpha_{0 i t}+\beta_{1} \text { LNSIZE }_{i t}+\beta_{2} \text { TAX }_{i t}+\beta_{3} \text { INTEN }_{i t}+\beta_{4} \text { DEV it }+\beta_{5} E_{\text {EVAR }}+\beta_{6} \text { DTEQU }_{i t} \\
& +\beta_{7} \text { ROA }_{i t}+\beta_{8} \text { CGDEP }_{i t}+\beta_{9} \text { ISSUE }_{i t}+\sum_{k} \gamma_{k} I_{\text {INDUSTRY }}+\sum_{l i t} \eta_{l} \text { YEAR }_{l i t}+\varepsilon_{i t}
\end{aligned}
$$

\begin{tabular}{|c|c|c|c|}
\hline Variable & $\begin{array}{c}\text { Expected } \\
\text { Sign }\end{array}$ & $\begin{array}{c}\text { Estimated } \\
\text { Coefficients }\end{array}$ & t-value \\
\hline Intercept & $+/-$ & 0.0944 & $20.47 * * * *$ \\
\hline LNSIZE & - & -0.0033 & $-10.76 * * *$ \\
\hline$T A X$ & + & O.1481 & $6.48 * * * *$ \\
\hline INTEN & $+/-$ & -0.0225 & $-6.13 * * *$ \\
\hline$D E V$ & + & 0.0277 & $5.71 * * *$ \\
\hline$E V A R$ & + & 0.0839 & $16.70 * * *$ \\
\hline DTEQU & $+/-$ & -0.0009 & $-8.52 * * * *$ \\
\hline$R O A$ & $+/-$ & 0.0197 & 0.83 \\
\hline$C G D E P$ & + & 0.3872 & $7.62 * * * *$ \\
\hline ISSUE & + & 0.1440 & $49.23 * * *$ \\
\hline F-value for Model & & $125.15 * * *$ & \\
\hline Adjusted $\mathbf{R}^{2}$ & & 0.2347 & \\
\hline $\mathbf{N}$ & & 19,029 & \\
\hline
\end{tabular}

\section{Notes:}

$\mathrm{t}$-value is based on a two-tailed test for variables without expected signs. *,**, and *** indicate significance at the 10,5 , and 1 percent levels, respectively. To keep the presentation brief, coefficient estimates for the 17 industry dummy variables and 21 year dummy variables are not presented.

See TABLE 2 for variable definitions.

Table 4

\begin{tabular}{|c|c|c|c|c|c|}
\hline & \multicolumn{2}{|c|}{ Profit \& } & \multicolumn{2}{|c|}{ Loss \& } & \multirow[b]{2}{*}{ Total } \\
\hline & Positive CEBR & Negative CEBR & Positive CEBR & Negative CEBR & \\
\hline Income Smoothing & $6,579(76.6 \%)$ & $6,526(80.3 \%)$ & $293(52.0 \%)$ & $1,049(59.8 \%)$ & $14,447(75.9 \%)$ \\
\hline Non-Income Smoothing & $2,007(23.4 \%)$ & $1,598(19.7 \%)$ & $271(48.0 \%)$ & $706(40.2 \%)$ & $4,582(24.1 \%)$ \\
\hline Total & $8,586(100.0 \%)$ & $8,124(100.0 \%)$ & $564(100.0 \%)$ & $1,755(100.0 \%)$ & $19,029(100.0 \%)$ \\
\hline
\end{tabular}

Smoothing Behavior by Operating Condition

Notes:

Computed Chi-Square statistic equals 33.87 for the profit group and 10.71 for the loss group.

Critical Chi-Square Value with degree of freedom 2 at one percent equals 9.210.

Note: $C E B R$ is the difference between actual income before provision on reserve accounts (i.e., $E B R_{\mathrm{t}}$ ) and expected income before provision on reserve accounts (i.e., $E B R_{\mathrm{t}-1}$ ).

Income (non-income) smoothing represents firm-years with positive (negative) IS. 
Table 5

Regression Results by Operating Conditions

\begin{tabular}{|c|c|c|c|c|}
\hline Variables & $\begin{array}{c}\text { (A) } \\
\text { Profit \& (+) CEBR } \\
\text { Estimated } \\
\text { Coefficients } \\
\text { (t-value) } \\
\end{array}$ & $\begin{array}{c}\text { (B) } \\
\text { Profit \& (-) CEBR } \\
\text { Estimated } \\
\text { Coefficients } \\
\text { (t-value) } \\
\end{array}$ & $\begin{array}{c}(\mathrm{C}) \\
\text { Loss \& }(+) C E B R \\
\text { Estimated } \\
\text { Coefficients } \\
\text { (t-value) } \\
\end{array}$ & $\begin{array}{c}\text { (D) } \\
\text { Loss \& (-)CEBR } \\
\text { Estimated } \\
\text { Coefficients } \\
\text { (t-value) }\end{array}$ \\
\hline Intercept & $\begin{array}{l}0.1085 \\
(15.77)^{* * * *}\end{array}$ & $\begin{array}{l}0.0961 \\
(13.92) * * *\end{array}$ & $\begin{array}{l}-0.0109 \\
(-0.25)\end{array}$ & $\begin{array}{c}0.0066 \\
(0.52)\end{array}$ \\
\hline LNSIZE & $\begin{array}{l}-0.0035 \\
(-7.65)^{* * *}\end{array}$ & $\begin{array}{l}-0.0038 \\
(-8.28) * * *\end{array}$ & $\begin{array}{l}-0.0002 \\
(-0.07)\end{array}$ & $\begin{array}{l}-0.0014 \\
(-1.75)^{*}\end{array}$ \\
\hline$T A X$ & $\begin{array}{l}0.0760 \\
(2.18)^{* *}\end{array}$ & $\begin{array}{l}0.1323 \\
(3.84) * * *\end{array}$ & $\begin{array}{l}-0.1233 \\
(-0.16)\end{array}$ & $\begin{array}{l}0.1157 \\
(0.80)\end{array}$ \\
\hline INTEN & $\begin{array}{l}-0.0174 \\
(-3.16)^{* * * *}\end{array}$ & $\begin{array}{l}-0.0277 \\
(-5.02)^{* * * *}\end{array}$ & $\begin{array}{l}-0.0677 \\
(-2.47)^{* *}\end{array}$ & $\begin{array}{c}-0.0120 \\
(-1.34)\end{array}$ \\
\hline$D E V$ & $\begin{array}{r}0.0046 \\
(0.60)\end{array}$ & $\begin{array}{l}0.0496 \\
(6.97)^{* * * *}\end{array}$ & $\begin{array}{l}0.1075 \\
(3.10)^{* * *}\end{array}$ & $\begin{array}{r}0.0049 \\
(0.43)\end{array}$ \\
\hline$E V A R$ & $\begin{array}{l}0.0946 \\
(11.55)^{* * * *}\end{array}$ & $\begin{array}{l}0.0805 \\
(9.04)^{* * * *}\end{array}$ & $\begin{array}{l}0.2022 \\
(7.00) * * *\end{array}$ & $\begin{array}{l}0.0395 \\
(4.40) * * *\end{array}$ \\
\hline DTEQU & $\begin{array}{l}-0.0012 \\
(-6.98)^{* * *} *\end{array}$ & $\begin{array}{l}-0.0011 \\
(-5.86)^{* * *}\end{array}$ & $\begin{array}{l}-0.0008 \\
(-1.91)^{*}\end{array}$ & $\begin{array}{l}0.0002 \\
(1.47)\end{array}$ \\
\hline$R O A$ & $\begin{array}{l}0.1752 \\
(4.23) * * *\end{array}$ & $\begin{array}{c}-0.0558 \\
(-1.24)\end{array}$ & $\begin{array}{l}-0.2737 \\
(-1.77)^{*}\end{array}$ & $\begin{array}{l}-0.2140 \\
(-4.60) * * *\end{array}$ \\
\hline$C G D E P$ & $\begin{array}{l}0.6169 \\
(7.70)^{* * * *}\end{array}$ & $\begin{array}{l}0.2903 \\
(3.75)^{* * * *}\end{array}$ & $\begin{array}{l}0.3622 \\
(1.16)\end{array}$ & $\begin{array}{l}0.0709 \\
(0.66)\end{array}$ \\
\hline ISSUE & $\begin{array}{l}0.0684 \\
(12.37)^{* * *}\end{array}$ & $\begin{array}{l}0.1598 \\
(45.70)^{* * * *}\end{array}$ & $\begin{array}{l}0.2796 \\
(1.36)\end{array}$ & $\begin{array}{l}0.4044 \\
(30.46)^{* * *}\end{array}$ \\
\hline F-value (Model) & $33.23 * * *$ & $96.20 * * *$ & $4.09 * * *$ & $26.48 * * *$ \\
\hline $\begin{array}{l}\text { Adjusted } \mathrm{R}^{2} \\
\mathrm{~N}\end{array}$ & $\begin{array}{c}0.1500 \\
8,586\end{array}$ & $\begin{array}{r}0.3552 \\
8,124\end{array}$ & $\begin{array}{c}0.2014 \\
564\end{array}$ & $\begin{array}{r}0.4057 \\
1,755\end{array}$ \\
\hline
\end{tabular}

\section{Notes:}

t-value is based on a two-tailed test. *, **, and *** indicate significance at the 10,5 , and 1 percent levels, respectively. To keep the presentation brief, coefficient estimates for the 17 industry dummy variables and 21 year dummy variables are not presented.

$C E B R=E B R_{i t}-E B R_{i t-1}$.

See TABLE 2 for all other variable definitions. 
Table 6

Regression Results by Pre and Post-1990 Periods

\begin{tabular}{|c|c|c|c|}
\hline Variables & $\begin{array}{c}\text { (A) } \\
\text { Pre-1990 } \\
\text { Estimated } \\
\text { Coefficients } \\
\text { (t-value) }\end{array}$ & $\begin{array}{c}\text { (B) } \\
\text { Post-1990 } \\
\text { Estimated } \\
\text { Coefficients } \\
\text { (t-value) } \\
\end{array}$ & $\begin{array}{c}\text { HO: } \\
\text { Pre = Post } \\
\text { (t-value })\end{array}$ \\
\hline Intercept & $\begin{array}{l}0.1030 \\
(12.37)^{* * *}\end{array}$ & $\begin{array}{l}0.0590 \\
(11.09)^{* * *}\end{array}$ & \\
\hline LNSIZE & $\begin{array}{l}-0.0050 \\
(-8.80)^{* * *}\end{array}$ & $\begin{array}{l}-0.0020 \\
(-5.38)^{*} * *\end{array}$ & $(-4.65) * * *$ \\
\hline$T A X$ & $\begin{array}{r}0.0219 \\
(0.51)\end{array}$ & $\begin{array}{l}0.1658 \\
(5.82)^{* * *}\end{array}$ & $(-3.32) * * *$ \\
\hline INTEN & $\begin{array}{l}-0.0264 \\
(-3.53)^{* * *}\end{array}$ & $\begin{array}{l}-0.0270 \\
(-6.31)^{* * *}\end{array}$ & $(1.48)$ \\
\hline$D E V$ & $\begin{array}{l}0.0227 \\
(2.72)^{* * * *}\end{array}$ & $\begin{array}{l}0.0269 \\
(4.32)^{* * * *}\end{array}$ & $(-0.29)$ \\
\hline$E V A R$ & $\begin{array}{l}0.0273 \\
(2.40) * *\end{array}$ & $\begin{array}{l}0.0968 \\
(17.35)^{* * * *}\end{array}$ & $(-5.37) * * *$ \\
\hline$D T E Q U$ & $\begin{array}{l}-0.0012 \\
(-6.90)^{* * * *}\end{array}$ & $\begin{array}{l}-0.0000 \\
(-0.36)\end{array}$ & $(-6.57) * * *$ \\
\hline$R O A$ & $\begin{array}{l}0.2409 \\
(4.87)^{* * * *}\end{array}$ & $\begin{array}{c}-0.0163 \\
(-0.59)\end{array}$ & $(5.07)^{* * * *}$ \\
\hline$C G D E P$ & $\begin{array}{l}1.1174 \\
(9.02)^{* * * *}\end{array}$ & $\begin{array}{l}0.1458 \\
(2.70)^{* * *}\end{array}$ & $(8.11)^{* * *}$ \\
\hline ISSUE & $\begin{array}{l}0.1734 \\
(37.91)^{* * * *}\end{array}$ & $\begin{array}{l}0.1032 \\
(25.37)^{* * * *}\end{array}$ & $(11.76)^{* * * *}$ \\
\hline $\begin{array}{l}\text { F-value (Model) } \\
\text { Adjusted R2 } \\
\text { N }\end{array}$ & $\begin{array}{l}80.52 * * * \\
0.3085 \\
6,595\end{array}$ & $\begin{array}{l}47.62 * * * \\
0.1452 \\
10,155\end{array}$ & \\
\hline
\end{tabular}

\section{Notes:}

$\mathrm{t}$-value is based on a two-tailed test. *,**, and *** indicate significance at the 10,5 , and 1 percent levels, respectively. To keep the presentation brief, coefficient estimates for the industry dummy variables and year dummy variables are not presented. Pre-1990 period includes years from 1982-1989 while post-1990 period includes years from 1992-1999.

See TABLE 2 for all other variable definitions. 